\title{
O PASSADO E A NECESSIDADE DE RUPTURA NO DISCURSO DA IMPRENSA SOBRE A PRIVATIZAÇÃO DAS TELECOMUNICAÇÕES
}

\author{
Fernando Felício Pachi Filho - Doutor em Lingüística (UNICAMP)
}

\section{RESUMO}

Este artigo analisa a função da representação do passado no discurso de jornais sobre a privatização das telecomunicações no Brasil. Por meio dos referenciais teórico-metodológicos da Análise do Discurso de linha francesa, observamos a inserção do acontecimento da privatização num eixo temporal em que a representação do passado contribui para que a privatização seja considerada uma ruptura, um evento fundador. Isso ocorre porque há reforço do discurso sobre a incapacidade de o Estado de gerir estas empresas, fator que teria levado ao caos nas telecomunicações e prejudicado a vida dos consumidores-cidadãos brasileiros. Alimenta-se assim o imaginário de um passado maléfico para a sociedade, devendo, portanto ser rejeitado em sua continuidade. Por esta razão, promove-se no discurso uma ruptura com este passado, estabelecendo na privatização o símbolo do novo. Naturaliza-se assim um sentido negativo para o passado.

Palavras-chave: Imprensa, Telecomunicações, Privatização, Análise do Discurso, Memória

ABSTRACT: This article analyses the role of the representation of the past in the discourse of newspapers about the privatization of telecommunications in Brazil. Through theoretical-methodological references of the French Discourse Analysis, we can observe the inclusion of the advent of privatization on a time line in which the representation of the past contributes to make the privatization a rupture, a breakthrough. That occurs due to the fact that there is reinforcement of the discourse about the inability of the State as far as managing these companies, which comes as a fact that would have taken telecommunications to chaos and worsened standards of living of Brazilian citizen-consumers. That has fostered the idea of the past being harmful to the society and should, therefore, be rejected in its continuity. Consequently, a rupture with the past is promoted in the discourse, having the privatization as the new symbol. A negative meaning is, thus, attached to the past.

Key words: Press, Telecommunications, Privatization, Discourse Analysis, Memory

\section{Introdução}

A privatização das telecomunicações no Brasil (1997/1998), tomada como acontecimento discursivo, provoca deslocamentos, regularizações e reorganizações na memória discursiva num jogo de forças que se dá entre a estabilização e a ruptura de sentidos (PÊCHEUX, 1999, p. 52). No discurso dos jormais $O$ Estado de S. Paulo e Folha de S. Paulo, que ora analisamos, a privatização é tomada como evento fundador de uma nova era para as 
telecomunicações e a sociedade em geral. Este evento é relacionado a um futuro pleno de benefícios e bem-estar. A organização no plano temporal proposta por estes jornais suscita ainda um questionamento sobre o passado. Que imagem de passado se constrói neste discurso? Em que medida é possível falar em ruptura na continuidade histórica a partir da privatização? Perguntas como estas se fazem necessárias para a compreensão do deslocamento discursivo proposto nos jornais analisados.

O que podemos observar é a inserção da privatização num eixo temporal em que o passado cumpre a função de estabelecer a base para que a privatização seja, de fato, considerada uma ruptura, um evento fundador. Isso ocorre porque a imagem de passado que a imprensa estrutura sobre o período em que as empresas de telecomunicações faziam parte do patrimônio do Estado reforça o discurso da ineficiência, da falta de investimentos e, conseqüentemente, de telefones; da incapacidade de o Estado gerir estas empresas, fatores que teriam levado ao caos nas telecomunicações e afetado negativamente a vida dos consumidores-cidadãos brasileiros. Alimenta-se um imaginário de um passado que produziu efeitos negativos para a sociedade, devendo, portanto, ser rejeitado e negado em sua continuidade. Por esta razão, promove-se no discurso uma ruptura com este passado, estabelecendo na privatização o símbolo do novo. (Figura 1)

Para tanto, temos a naturalização de um sentido negativo para o passado. A imprensa dispõe uma organização imaginária do passado, buscando legitimar e consolidar um lugar para a privatização, para a emergência do privado, numa linha lógica e explicativa. Elias (1998, p.152) adverte que a concepção do passado como história favorece a percepção de descontinuidades, habituando o ser humano a pensar no passado como multidão de períodos não ligados entre si. Pela construção de uma ruptura na história econômica do país, produz-se então a percepção de que não haverá permanência do passado no presente, 
marcando a descontinuidade.

Para Henry (1994), não há "fato" ou "evento" histórico que não faça sentido, que não exija interpretação. A história, portanto, consiste em fazer sentido, que está sempre já-lá e se presta a correções, retificações, nuances. Os fatos têm assim historicidade. A partir desta reflexão de Henry, podemos pensar sobre a função que uma certa imagem de passado desempenha para o significado mesmo da própria privatização, num progressivo deslocamento da memória em prol do que é privado e na desvalorização de uma história, que teve no estatal sua marca.

1.

\section{O passado como argumento}

Observamos em relação ao discurso sobre a privatização o fato de que se estabelece um agenciamento do imaginário sobre o passado, que se estabiliza como referência na justitificativa para a própria privatização. Desta forma, o passado é um argumento que funciona neste discurso, permitindo a cristalização dos sentidos positivos em torno da privatização. Estabelece-se assim um saber sobre a história que compõe o acontecimento discursivo da privatização, que emerge como necessidade nesta história contada pela imprensa e promove deslocamentos de sentidos na rede de memória. A imprensa produz o lugar de construção de uma memória e de uma interpretação sobre o passado. Igualmente, o que se tem é um efeito de unicidade e transparência. É a partir da construção da imagem deste passado em textos publicados nos jornais que é possivel falar numa ruptura, numa "revolução" ou numa "nova era". Pretende-se um controle sobre o tempo, por sujeitos que ocupam a posição de observadores e avaliadores deste passado, colocando-se externanemte a ele. Desse modo, acontecimentos históricos descontínuos se inserem na continuidade interna e no espaço de coerência de uma memória (PÊCHEUX, 1999, p. 50)

Pensamos, assim como Mariani (1993), que a imprensa estabelece um controle do imaginário político do passado, produzindo "uma certeza" sobre este passado, não explicitando as relações de força que o fixam e silenciando outras versões, de modo a produzir uma unicidade que passe a funcionar para o estabelecimento do discurso sobre a atualidade. A imprensa configura-se como lugar de produção de um dos discursos sobre a história, instaurando uma versão sobre os fatos, ligada a uma verdade sobre eles. Dessa forma, busca-se construir uma história comum, uma identidade histórica, que pode ser evocada para a explicação do presente. Esta versão apresentada pela imprensa se impõe como sentido dominante, institucionalizado e legítimo. A mídia constitui o imaginário social, como produtora de uma história do presente e de uma visão sobre o passado, que integra este imaginário disponibilizado na circulação 
desse discurso.

\section{A função do passado}

Em seu movimento de fixar uma interpretação para o passado, a imprensa busca, de modo geral, atender a uma necessidade de sua constituição discursiva. Podemos assim falar sobre uma função do passado neste discurso. No discurso sobre a privatização, o relato do passado contribui para sustentar os efeitos insatisfatórios deste passado no presente. Por essa razão, a reflexão sobre o presente convoca o retorno do passado para fazer sentido no presente e determinar interpretações. Produzir um sentido para o passado anterior à privatização é, portanto, necessário para a instauração da privatização como evento fundador e para reorganizar os sentidos na valorização do que é privado. Constrói-se uma memória sobre o passado em função da necessidade de tornar a privatização um evento histórico.

No campo da história, esta discussão remete a uma necessidade do presente de interpretar o passado para responder a questões da atualidade. Le Goff (1992) explica que a oposição entre passado/presente é fundamental para a consciência do tempo. A discussão, porém, no campo da história, mostra que esta oposição não é um dado natural, mas uma construção permanente. A imagem do passado é sempre feita a partir de um presente, tempo do historiador, o que já demonstra a inserção deste discurso na história.

Da mesma forma, o jornal produz interpretação sobre o passado, na tentativa de estabelecer uma compreensão para o presente. Busca-se, porém, ainda estabelecer uma interpretação e apagar o fato de que este passado é formulado a partir do presente, imobilizando a interpretação e negando-a. No discurso sobre a privatização nos jormais analisados, o efeito é de uma exatidão da interpretação histórica, que visa estabelecer um sentido, regularizar o caos dos acontecimentos e suprimir falhas, equívocos que apontam para outros sentidos possíveis. Mas, como explica Le Goff (1992), o movimento de interpretação do passado é contínuo e o que ocorre são novas leituras, "plenas de perdas, ressurreições, falhas de memória e revisões" (LE GOFF, 1992, p. 28). O fato histórico, assim como o jornalístico, é construído.

De Certeau (1982) explica que a separação entre presente e passado corresponde a um gesto de divisão, que instaura um discurso autorizado a falar sobre o passado, que dele se afasta considerando-o seu precedente. Alerta o autor que é necessário ter em mente que este passado é marcado também por cortes anteriores. Tomado como objeto a partir de uma perspectiva presente, o passado pode ser narrado e ter seus sentidos estabelecidos. Há, segundo De Certeau, um trabalho de distinção entre o que pode ser "compreendido" e o que deve ser esquecido, que resulta na representação da inteligibilidade presente 
(DE CERTEAU, 1982, p.15-16). Nesta perspectiva, a história é uma ficção do presente. Pelos esquecimentos produzidos e pelas falhas na interpretação histórica, segundo o autor, seria possível estabelecer outras leituras para a história. Não haveria, portanto, a possibilidade de uma sistematização totalizante, pois o discurso que fala da história situa-se na história e está preso na sua historicidade.

O discurso jornalístico, assim como o da história, articula saber e poder para produzir interpretações num jogo complexo de forças na sociedade, em que pesam o trabalho do jornalista, a instituição jornalística, que determina regras de produção, o leitor imaginado e as relações com as próprias instâncias de poder. Há, portanto, uma série de constrangimentos, internos e externos à instituição jornalística, que atuam na elaboração dos textos jornalísticos e, conseqüentemente, do sentido. De modo geral, o jornalismo atribui-se a tarefa de produzir, classificar e hierarquizar sentidos para a realidade, transformando acontecimentos em fatos, numa lógica de produção de notícias. Podemos, então, falar numa ordem do discurso jornalístico, na qual se produzem interpretações de acontecimentos selecionados pela imprensa e considerados importantes. Há um processo permanente, na produção desse discurso, de seleção, exclusão, atualização de acontecimentos, que devem, portanto, ser presentificados para se textualizar nas páginas dos jornais. Desta forma, constrói-se uma interpretação que se impõe a ler (MARIANI 1999, p. 105), apagada no efeitoleitor produzido. Temos então uma instituição, no caso os jornais, que impõe visões de mundo ordenadas e naturalizadadas no espaço público. Neste processo, produz-se um conhecimento - tido como verdadeiro - sobre a realidade, sobre o presente e o passado, num efeito ideológico de imparcialidade e objetividade.

Orlandi (1998) explica que há uma gestão da memória coletiva pelos aparelhos de poder que promove uma divisão entre autores e intérpretes. A decorrência disso é a administração dos sentidos, que não andam soltos, e se relacionam à posição dos sujeitos. Neste aspecto, a mídia é uma agenciadora de sentidos que seleciona o que deve ser apreendido como sentido único e o que pode ter muitas interpretações (ORLANDI, 1998, p. 96). A instituição jornalística tem seus procedimentos de controle e interdição de sentidos, estabelecendo uma ordem discursiva que alimenta o discurso social e a disputa pelos sentidos na sociedade.

\section{Argumento e espaço de memória}

Delimita-se assim na representação negativa do passado um espaço de memória, que é também espaço de esquecimento e que cumpre a função argumentativa baseada na ilusão de um passado homogêneo, não-contraditório e interpretável como verdade. Ao ser constituído como argumento o passado mantém com o presente uma relação também não-contraditória e lógica. $\mathrm{O}$ 
presente, representado pela privatização, é conseqüência deste desdobramento, sendo que a ruptura em relação a este passado é necessária para que não haja reprodução destes "erros". Dessa forma, a interpretação deste passado produz o efeito de sustentação da privatização. Além disso, os jornais trazem uma interpretação sobre o passado, organizado por eles, e buscam inseri-la num discurso de explicação para o acontecimento da privatização.

Este recorte, lugar de identificação e interpelação ideológica, torna-se argumento, um meio de conhecimento do passado que justifica a ruptura com ele, propiciando o deslocamento em direção ao privado, associado ao futuro. Esta gestão do tempo histórico, atribuindo-se um sentido a este tempo, produz uma linha de continuidade entre presente e futuro e uma ruptura entre passado e presente, deslocando a memória para o futuro e desqualificando uma certa imagem do passado. A história, usada para fazer história, é representada como um trajeto unidirecional e linear. Desta forma, este discurso lineariza e logiciza a história. O passado, tomado como identidade comum, retorna no presente como argumento produzindo ainda o efeito de repetição e reconhecimento, inserindose numa rede de formulações (PÊCHEUX, 1999, p. 51).

Orlandi (1998, p. 49-50) explica que a argumentação deve ser vista, em Análise do Discurso, no processo histórico de constituição das posições dos sujeitos. Neste aspecto, a instância da formulação, na qual haveria a intencionalidade, está determinada pelas diferentes posições discursivas dos sujeitos. As filiações ideológicas, neste ponto, já estão definidas e a argumentação não afetaria as posições dos sujeitos. O sujeito já tem assim sua posição determinada, já está sob o efeito da ilusão subjetiva e, em seu imaginário, está afetado pela vontade de verdade, pelas evidências de sentido e pela ilusão referencial. Os argumentos são produzidos pelos discursos, em relações histórica, política e ideologicamente determinadas.

\section{Interpretações sobre o passado}

Nos textos ${ }^{[1]}$ abaixo, procuramos explicitar o funcionamento do passado como argumento, bem como efeito de explicação que se obtém do uso de uma determinada interpretação deste passado, numa relação de ruptura no presente e descontinuidade no futuro. Notemos que o passado tomado como argumento reforça a apologia à privatização, já que ela se constitui como solução para um passado que produziu efeitos indesejáveis, que impôs obstáculos para o desenvolvimento do País e com o qual deve-se romper. O apelo à história vem deste modo compor o quadro favorável à privatização e deslocar sentidos positivos em direção ao que é privado, reafirmando a necessidade de remodelação da função atribuída ao Estado. 

na velocidade dos nossos sonhos, mas avança. Hoje, alguns debatem o valor, a forma de pagamento, o momento para realizar a privatização. Entretanto, a grande maioria da sociedade - exceção à parcela de intervencionistas que continua defendendo estatais gestadas no auge do regime militar considera irreversível o processo de desestatização da economia brasileira e julga fundamental que seja implementado o mais breve possível.

Há algum tempo, jamais imaginaríamos presenciar o ocorrido em 29 de julho de 1998, data histórica que marca o início da derrocada do Estado-empresário brasileiro. No "bater do martelo", desfaz-se um dos maiores símbolos da retrógrada visão do Estado intervencionista e do dirigismo econômico: a Telebrás, empresa que, ao longo de sua história, mostrou-se incapaz de realizar sua missão de desenvolver o sistema de comunicações do país.

O Estado era o poder concedente e o poder concessionário monopolista dos serviços de telecomunicações. Resultado óbvio: o Brasil entre os países com a pior telefonia do mundo, com uma demanda reprimida atual calculada em 17 milhões de telefones fixos e 8 milhões de aparelhos celulares.

A privatização da Telebrás, mais do que os altíssimos valores a ser carregados aos cofres do erário, apresenta o simbólico significado de colocar uma pá sobre a ultrapassada visão nacionalista segundo a qual setores supostamente estratégicos devem permanecer sob a tutela do Estado ou merecer reservas de mercado. Atualmente, parece fácil compreender que a falta de competição e de compromisso com a satisfação do cliente gera uma ineficiência patológica nos serviços prestados pelo Estado.

Não devemos esquecer que, até pouco tempo atrás, essa idéia era considerada rematada loucura. Homens esclarecidos, como o deputado Roberto Campos, com a autoridade que lhe confere o fato de ter sido um dos criadores da infra-estrutura estatal brasileira, durante anos pregaram no deserto, dedicando centenas de ensaios a irradiar um pouco de luz na escuridão que dominava o pensamento de nossos governantes.

O dramático é que as discussões, dominadas que eram pela demagogia e pelo fisiologismo político, sempre geraram muito mais calor do que luz, não contribuindo para conscientizar a população, acionista maior das empresas estatais. Quando olhamos o passado, vem à mente a pergunta fundamental: por que esperamos tanto? Por que deixamos que a necessidade de salvar um Estado falido exigisse a ação se poderíamos tê-la realizado previamente?

A resposta não é difícil: recebemos uma cultura ibérica patrimonialista, que fez com que acreditássemos que o Estado deve ser o gestor da economia e que nos acostumou a aceitar a baixíssima qualidade dos serviços por ele prestados. $O$ corporativismo daqueles que sempre se beneficiaram com o Estado também ajuda a entender a demora do processo.

A essência é a compreensão de que o papel do Estado não é empreender. Isso sempre será mais bem desempenhado pela sociedade, na forma do que chamamos iniciativa privada. Quando houver um entendimento profundo do prejuízo causado a todos quando o Estado vira empresário, com certeza estaremos vivendo uma sociedade mais rica e justa.

Erram aqueles que temem que o Estado esteja sendo esvaziado. Em verdade, ele deve diminuir seu tamanho justamente para atuar com mais proficiência em suas atividades precípuas, como a Justiça e a segurança, tarefas que vêm sendo negligenciadas.

Na mudança dessa atávica cultura e na aposta na economia de livre mercado está a essência de um desenvolvimento sustentado e de uma maior prosperidade.

Embora muito ainda tenhamos de fazer, gratifica-nos constatar que estamos andando no caminho correto e que a população em geral, antes muda, sem poder ouvir ou falar, passa a ter a chance de contar com serviços à altura de suas necessidades.

Como de sonhos, que parecem impossíveis, surgem as grandes mudanças na sociedade, quem sabe um dia... Petrobrás... Banco do Brasil...(GORON, F. e LEWIN, S., 1998, p. 2-2). 
No texto acima (1), o sujeito coloca-se do lado da "grande maioria da sociedade", em oposição a uma parcela "de intervencionistas que continua defendendo estatais gestadas no auge do regime militar". Há a permanência de um passado que remonta ao regime militar, controverso e condenado numa avaliação histórica produzida na contemporaneidade. O verbo "continuar" seguido por "defender" no gerúndio marca a continuidade deste passado no presente. Organiza-se, desta forma, o sentido de que há apenas uma parcela que defende as estatais e que este grupo está na linha de continuidade do regime militar. Além disso, o texto se inicia falando de um avanço da sociedade, que pode ser identificado na seqüência com a privatização. E esta maioria, que se localiza no jogo de forças pró-privatização, é a que considera o processo de desestatização "irreversível". Ao situar a privatização na sua irreversibilidade, o sujeito coloca-se no exterior do processo histórico, na categoria de observador de algo que se desenvolve independentemente das forças político-econômicas que intervêm na privatização, que deve ser "implementada" o mais breve possível. O Estado-empresário é significado no passado, como anterior à privatização, dêixis de uma mudança ("o início da derrocada do Estadoempresário brasileiro"). Observemos que este Estado é qualificado a partir da consideração de que ele corresponde a uma visão retrógrada, intervencionista e de dirigismo econômico, do qual a Telebrás é um simbolo. Notemos ainda que o aposto "empresa que, ao longo de sua história, mostrou-se incapaz de realizar sua missão de desenvolver o sistema de comunicações do país" recorta do interdiscurso ${ }^{[2]}$ a incapacidade de uma empresa sob tutela do Estado em cumprir sua missão.

Num segundo momento, busca-se vincular este passado em que o "Estado era o poder concessionário monopolista dos serviços de telecomunicações" com o resultado desta política: "Resultado óbvio: o Brasil entre os países com a pior telefonia do mundo, com uma demanda reprimida calculada em 17 mihões de telefones fixos e 8 milhões de aparelhos celulares." Novamente, a privatização é considerada um marco simbólico que vem superar uma "ultrapassada visão nacionalista", em que setores que seriam "supostamente estratégicos" devem permanecer sob a tutela do Estado ou "merecer reservas de mercado". O advérbio "supostamente" é uma marca da avaliação que o sujeito faz da posição do outro, da veracidade do dizer do outro. Assim, ele instaura sua versão, ou seja, o setor de telecomunicações não é estratégico, tomando a verdade para si. Dessa forma, "falta de competição" e de "compromissos com a satisfação do cliente" são tidos como causa de "ineficiência patológica" de serviços prestados pelo Estado. Olhar o passado é, portanto, um movimento que tenta explicar a necessidade de mudança e desvalorizar discursos antagônicos, representados como não verdadeiros. Por essa razão, este passado configura-se como argumento, promovendo deslocamento na rede de memória para que ele funcione como tal. Assim, localiza-se numa "cultura ibérica patrimonialista", 
como agente de uma crença no Estado como gestor da economia e que teria nos acostumado a baixa qualidade de serviços. Haveria ainda outra razão para a demora nas mudanças: "o corporativismo daqueles que sempre se beneficiaram com o Estado também ajuda a entender a demora do processo."

Esta interpretação do passado corresponde a um movimento do sujeito para buscar neste passado justificativas para sua tomada de posição na rede de memória, fixando uma interpretação que se define como verdade, que pode ser afirmada:

A essência é a compreensão de que o papel do Estado não é empreender. Isso sempre será mais bem desempenhado pela sociedade, na forma do que chamamos iniciativa privada. Quando houver um entendimento profundo do prejuízo causado a todos quando o Estado vira empresário, com certeza estaremos vivendo uma sociedade mais rica e justa.

Dessa forma, esta verdade, marcada pelas asserção ("A essência é compreensão de que o papel do Estado não é empreender"), e enfatizada pelo advérbio "sempre", que a eleva a uma duração no tempo para além desta interpretação, é um efeito neste discurso. Sua aceitação é condição para uma sociedade "mais rica" e "mais justa", que se pereniza no futuro contínuo, marcado em "estaremos vivendo".

Ao produzir efeitos de verdade, o sujeito se fixa como quem pode considerar errada quem toma outra posição: "Erram aqueles que temem que o Estado esteja sendo esvaziado". A este erro se opõe uma "verdade", que leva a uma obrigação, marcada pelo verbo dever. ("Em verdade, ele deve diminuir seu tamanho'). Este será o “caminho correto”, de um “desenvolvimento sustentado” e "de uma maior prosperidade".

Existe um erro de enfoque nessa gritaria contra a privatização. O ponto central das críticas não deveria ser contra a privatização em si, mas no sentido de aprimorar o novo modelo proposto.

A história econômica e política do país neste século consagrou um modelo de intervenção direta do Estado sobre a economia. Na política industrial e na prestação de serviços públicos, o Estado tinha de estar presente em todas as etapas - da definição de leis à operação dos serviços. Ou seja, na regulação e na operação.

Esse modelo funcionou em alguns momentos da história. Depois, vieram a impossibilidade de a atuação do Estado ficar ao largo das interferências políticas em ambiente democrático e a complexidade cada vez maior do mundo moderno, tirando a eficácia das ações centralizadas.

No novo modelo, irreversível, o Estado atua como agente regulador, definindo normas, induzindo as ações do setor privado e fiscalizando sua implementação. O grande instrumento dessa política são as novas agências de regulação que estão sendo criadas.

Novo controle

No modelo de Estado que existia até então, havia inúmeras formas de burlar o controle social. Em empresas, há uma multiplicidade de contratos, atos de diretoria, ações estratégicas, contratações impossíveis de ser fiscalizadas no dia-a-dia.

No modelo de Estado regulador, o universo de ações a ser fiscalizado reduz-se sensivelmente. Primeiro, há a definição de leis e 
regulamentos. Depois, sua implementação.

Empresas que assumem serviços públicos têm de cumprir determinados quesitos de qualidade e desempenho. A fiscalização da opinião pública se dá, especificamente, em cima desses indicadores.

Para que o modelo funcione a contento, no entanto, é fundamental que haja uma ampla discussão acerca das leis e normas que regerão os setores e a ação das agências de regulação.

Em vez de deblaterar contra o novo modelo, toda essa energia deveria estar sendo voltada para o aprimoramento das novas formas e para a busca de controle e transparência sobre as agências de regulação.

Tome-se o caso das telecomunicações. Há receio de que a nova regulação permita a consolidação de supergrupos de comunicação sobre o país, assumindo de fato um controle oligopolístico sobre a opinião pública. No setor elétrico, há receios de que uma regulação frouxa leve à deterioração dos serviços oferecidos e à elevação dos preços.

Em tese, tudo isso pode ser evitado por essas novas agências, desde que sejam forjadas dentro dos valores de uma economia de mercado sadia - prevendose a manutenção do ambiente competitivo, dos objetivos sociais (especialmente em áreas de serviço público) e da plena transparência de suas ações.

É o que está ocorrendo com o Conselho Administrativo de Defesa Econômica (Cade), por exemplo, que está consolidando uma cultura antioligopólio forjada na sua atuação diária - não em um regulamento ou lei que pode virar letra morta mais adiante.

A esta altura da história, em vez de catilinárias contra a privatização, juristas e políticos de oposição deveriam dirigir toda a sua energia e capacidade de análise para prevenir defeitos de nascença que possam atrapalhar a ação das futuras agências de regulação. (NASSIF, L., 1997, p.2-2).

Observemos em (2) que o sujeito ocupa a posição de comentar e considerar o erro dos que se opõem à privatização. Dessa forma, a partir da consideração de que há uma verdade e de que a oposição a esta verdade é um erro, pode-se mostrar a necessidade de deslocamento da posição ocupada pela oposição: “O ponto central das críticas não deveria ser contra a privatização em si, mas no sentido de aprimorar o novo modelo proposto." A oposição deveria integrar-se a um modelo, que já é significado como "novo", que implicitamente se opõe a antigo ou velho.

O passado também marcado lingüisticamente nos verbos no perfeito (consagrou) e no imperfeito (tinha) pretende fechar um campo para a atuação do Estado. Num primeiro movimento, esta história consagra ao longo do tempo um modelo, que se situa no passado e não deve ter ecos no presente (“a história econômica do país neste século consagrou um modelo de intervenção direta sobre a economia”). A duração no passado, não mais necessária no presente, é marcada pelo imperfeito "tinha": "Na política industrial e na prestação de serviços públicos, o Estado tinha de estar presente em todas as etapas - da definição de leis à operação dos serviços. Ou seja, na regulação e na operação”. O sujeito reconhece que este modelo produziu efeitos positivos ao longo de sua história ("funcionou em alguns momentos da história").

Em um momento não determinado, marcado apenas pelo advérbio “depois", que une o passado a um cenário posterior que impossibilitou "a atuação do Estado ficar ao largo das interferências políticas em ambiente democrático e a complexidade cada vez maior do mundo moderno, tirando a eficácia das ações centralizadas”. Dessa forma, um modelo que era eficiente 
torna-se inadequado no presente, o que justifica sua mudança, explicada à luz da história. O discurso se estrutura entre a categorização do novo modelo como algo "irreversível", que foge ao controle, portanto, e de um modelo que se situa no passado. Assim, no novo modelo "o Estado atua como agente regulador, definindo normas, induzindo as ações do setor privado e fiscalizando sua implementação".

Notemos que este Estado é atuante, ao contrário do Estado anterior que "existia até então", em que "havia inúmeras formas de burlar o controle social", características indesejáveis e que pertencem ao passado. No modelo de Estado regulador, que se associa ao novo (reescrito em "novo modelo"), há "definições de leis e regulamentos", "implementação" e obrigação de cumprimento de quesitos de "qualidade e desempenho". Dessa forma, o novo modelo é superior ao antigo, não sendo passível de contestação, já que ele se baseia num desenvolvimento histórico, que provou ser insuficiente e inadequado para os novos tempos. Daí a necessidade de ênfase para silenciar a oposição, que deveria concentrar suas energias no aprimoramento do novo: "Em vez de deblaterar contra o novo modelo, toda essa energia deveria estar sendo voltada para o aprimoramento das novas formas e para a busca de controle e transparência sobre as agências de regulação"; e "A esta altura da história, em vez de catilinárias contra a privatização, juristas e políticos de oposição deveriam dirigir toda a sua energia e capacidade de análise para prevenir defeitos de nascença que possam atrapalhar a ação das futuras agências de regulação"

(3)

O Brasil desestatizou este ano todos os serviços de telefonia. Para a esquerda estatista e os grupos corporativistas, foi um erro. Vendeu-se um setor estratégico. O país perdeu. A soberania foi ferida. Será?

Felizmente, essa avaliação está equivocada. O Brasil vai ganhar. Juntamente com a concessão da banda B da telefonia celular, a privatização da telefonia fixa acarretará mudanças rápidas nas telecomunicações, beneficiando todos os usuários.

$\mathrm{O}$ foco da desestatização foi a concorrência. Na telefonia celular, onde esta já chegou, a revolução é inequívoca. Os preços despencam, a competição se acirra, os consumidores se tornam o centro das estratégias mercadológicas das empresas.

Em São Paulo, a concessionária BCP Telecomunicações lançou ampla campanha promocional ligada ao Natal: quem adquirir uma linha ganha outra de graça. Assinantes recebem um cupom de R\$100,00, que pode ser usado para pagar parte do aparelho.

Em Minas Gerais, a Telemig Celular e a Maxitel se digladiam para conquistar assinantes para seus telefones celulares. Oferecem habilitação gratuita e produtos especiais como o telefone de cartão.

No Rio de Janeiro, a Telerj Celular baixou em 75\% o valor da habilitação, que agora custa apenas $\mathrm{R} \$ 80,00$. Sua concorrente, a ATL, promete competição para valer, ainda que não possa operar no interior do Estado.

Na Bahia, a Telebahia Celular e a Maxitel também estão oferecendo habilitação gratuita e tarifas diferenciadas por tipo de cliente.

Mesmo que as vozes que se antepuseram à privatização o desejem, não dá para esconder a mudança para melhor no quadro das telecomunicações no Brasil.

É claro que falta muito. Na telefonia fixa, o serviço ainda tem a ineficiência dos tempos estatais. No Rio, é um tormento conversar pelo telefone em certos momentos. Fazê-lo de São Paulo para o Nordeste nos domingos à tarde é um exercício de paciência. 
Preso a um Estado em crise e à reserva de mercado da informática, o Sistema Telebrás andou a passo de cágado a partir dos anos 80, enquanto em outras partes do mundo as telecomunicações se revolucionavam com a desregulamentação e o avanço tecnológico.

Chegamos ao final do século na incômoda posição de um dos países lanterninhas na oferta de telefones à população: apenas 10 linhas por grupos de 100 habitantes. Aqui na América Latina, Argentina e México têm o dobro disso. Na Europa, acima de 60.

Em quatro anos, depois de investir obrigatoriamente perto de R\$ 10 bilhões anuais, as empresas privatizadas terão aumentado essa relação para 17 linhas por 100 habitantes. Ainda assim, estaremos abaixo da Costa Rica, onde a relação é de 25 por 100.

Seja como for, é preciso saudar os acontecimentos. Apesar da longa estrada a percorrer para recuperar o terreno perdido, a mudança no ambiente já produz efeitos, mesmo na telefonia fixa, como mostra o comportamento do mercado secundário.

Na época da estatização, o Brasil era um caso curioso: possuía um vigoroso mercado secundário de telefones. Corretores enriqueceram com a escassez de linhas produzida pelo Estado. Esse mercado ainda sobrevive, mas está em processo de extinção.

No início desta década, uma linha telefônica custava mais de R\$ 3 mil em São Paulo. Em áreas congestionadas, como a da Barra da Tijuca, no Rio de Janeiro, chegou-se à exorbitância de R \$ 17 mil por linha.

Agora, os preços de uma linha nesses dois mercados estão em $\mathrm{R} \$ 300,00$ e $\mathrm{R} \$ 800,00$, respectivamente. Em breve, as empresas deverão atender um pedido de nova linha, sem custos ou ágios, em apenas uma semana. Nos EUA, são 24 horas.

Até aqui falamos apenas dos benefícios evidentes para o sofrido consumidor de telefones no Brasil. Muito se dirá ainda sobre o aumento de eficiência das empresas e da competitividade dos produtos, que se traduzirão em mais renda, emprego e bem-estar.

É uma pena que a esquerda atrasada, incluindo amplos segmentos bem intencionados, mas desinformados do sindicalismo, não tenham sido capazes de perceber os novos ventos. Quem sabe a experiência recente lhes forneça alguma lição útil.

Há muitas mudanças em curso. Uma das mais prosaicas será a necessidade de os contribuintes do Imposto de Renda cancelarem o valor das linhas telefônicas constantes de suas declarações de bens. Essa era outra esquisitice nossa área das telecomunicações. Linha telefônica está deixando de ser um ativo em que se podia investir. Virou presente de Natal, que será cada vez mais difundido à medida que caem os preços. (NÓBREGA, M., 1998, p. 2-2)

Notemos que em (3) o Brasil vem designar o Estado brasileiro que promoveu a desestatização. "Estatista" é um qualificativo de "esquerda" que integra juntamente com os corporativistas o grupo de oposição, dos que consideram a privatização um erro ("vendeu-se um setor estratégico", "o país perdeu", "a soberania foi ferida"). Ao expor argumentos atribuídos a esta oposição, o sujeito distancia-se desta posição e por uma pergunta retórica ("Será?"), que provoca o efeito de contestação do discurso do outro, incorporado em seu discurso, ocorre a transição para sua posição, contrária à interpretação oposicionista. O advérbio "felizmente" ("Felizmente, essa avaliação está equivocada") também promove este deslocamento, transferindo para o campo do equívoco a versão da oposição. O equívoco é do outro, o que implicitamente também transfere a verdade e a razão para o sujeito que toma posição contrária. Desloca-se para o futuro - "O Brasil vai ganhar, a privatização da telefonia acarretará mudanças rápidas nas telecomunicações, beneficiando todos os usuários" - o ganho que supera a perda para o país, propalada pela oposição. Apresentam-se também os argumentos que permitem comprovar que a 
revolução é "inequívoca", só atingida porque houve a privatização - "os preços despencam, a competição se acirra, os consumidores se tornam o centro das estratégias mercadológicas das empresas". Observemos a ênfase na "ineficiência dos tempos estatais", marca de um período que se quer superar. Dessa forma, o estatal se associa à ineficiência. O recurso a uma avaliação histórica vem explicar esta ineficiência, condenando o modelo anterior e valorizando o novo. Por isso, as causas do atraso relacionam-se a este modelo existente num Estado em crise e protecionista em relação à informática, como observamos abaixo:

\begin{abstract}
Preso a um Estado em crise e à reserva de mercado da informática, o Sistema Telebrás andou a passo de cágado a partir dos anos 80, enquanto em outras partes do mundo as telecomunicações se revolucionavam com a desregulamentação e o avanço tecnológico.

Chegamos ao final do século na incômoda posição de um dos países lanterninhas na oferta de telefones à população: apenas 10 linhas por grupos de 100 habitantes. Aqui na América Latina, Argentina e México têm o dobro disso. Na Europa, acima de 60.
\end{abstract}

O setor privado, diante da ineficiência estatal, vem para "recuperar o tempo perdido" num processo de mudança que já produz efeitos e necessita ser saudado por todos, ou seja, a expressão "é preciso" universaliza esta necessidade, tornando a privatização e as mudanças ocorridas incontestáveis, já que os benefícios são "evidentes". Outros benefícios são projetados no futuro: "aumento de eficiência e da competitividade dos produtos, que se traduzirão em mais renda, emprego e bem-estar"

Diante de todas as provas apresentadas, a esquerda é identificada com a posição estatista e se aproxima do atraso. Dessa forma, é necessário que eles aprendam: "É uma pena que a esquerda atrasada, incluindo amplos segmentos bem intencionados, mas desinformados do sindicalismo, não tenham sido capazes de perceber os novos ventos. Quem sabe a experiência recente lhes forneça alguma lição útil." Notemos que a expressão "é uma pena" vem traduzir a posição inequívoca de verdade, na perspectiva que se situa o sujeito universal ${ }^{[3]}$, que pode, neste caso, desconsiderar outras versões para a privatização.

(4) O único mudo na gritaria da privatização da Telebrás é justamente o único que deveria falar mais alto e impor sua vontade: o MST - Movimento dos Sem-Telefone. São os 17 milhões de brasileiros, pessoas e empresas, que estão na fila de uma humilde linha telefônica sem obter um mísero chiado do monopólio estatal do malote e do recado. Também integram o MST da telecomunicação os 7 milhões de brasileiros na fila bola-de-neve do celular, nova paixão nacional. Eis a questão. O Sistema Telebrás funcionou até aqui no figurino de uma estatal soviética. Ou seja: de costas para o mercado, para a nação, para o mundo e para o futuro. Ainda hoje, na Grande Rússia, consumidores micados aguardam a entrega do primeiro carro particular, devidamente pago há mais de dez anos. E o carro da fila é um Lada. Foi essa anorexia econômica que destruiu a União Soviética e respectivos satélites. Sem que fosse preciso disparar um tiro, uma 
revolta, uma passeata, uma greve, um manifesto.

Até a China, que ainda está comunista, já ligou o desconfiômetro e partiu para a flexibilização do monopólio estatal da telecomunicação. A velha guarda do PC chinês entende que o patrimônio verdadeiramente estratégico de uma nação é a qualidade de vida de sua população. Descoberta dos socialistas fabianos na virada do século 20 e materializada pelo "welfare state" do capitalismo digno do nome nos dois lados do Atlântico Norte. Investimento estratégico do Estado moderno não é telefone, não é petróleo, não é asfalto, não é energia, não é ferrovia. Soberania nacional é concentrar capitais públicos (escassos) e capitais privados (suplementares) em saúde pública, educação pública, segurança pública, justiça capilar, transporte coletivo, habitação popular, pesquisa básica e programas sociais de emergência. São funções de governo para todo o sempre. Governo eficiente e enxuto, no conceito do Estado Ótimo e não mais do Estado Máximo ou do Estado Mínimo.

O pano de fundo doutrinário dessa nova percepção universal está na socialização do produto (via tributação) e não na socialização da produção (via estatização). O segundo modelo já foi testado, reprovado e sepultado em esquife de quinta classe no cemitério das utopias fraudadas. $\mathbf{O}$ primeiro modelo, o vitorioso, exige a salvaguarda do Estado arbitral, dono da autoridade (e não da propriedade) do processo econômico. O mercado que se aproxima não está em oposição ao Estado. Essa visão maniqueísta é canastrice ideológica. Mercado que se desenha no horizonte do terceiro milênio não será aberto nem fechado. Será, digamos assim, um mercado liberal dentro da moldura do Estado arbitral. Um mercado regulado ou pactuado, dentro de uma "banda larga" de competição ou concorrência. A competição garante a transferência forçada dos ganhos do acionista para os preços do consumidor. E, quando o consumidor ganha, ninguém perde. $\mathrm{Na}$ telecomunicação brasileira, o consumidor do monopólio estatal é o perdedor resignado. Em quantidade do produto e em qualidade do serviço. Basta. (BETING, J., 1998, p.B2)

No texto (4), podemos compreender como se estruturam a oposição entre novo e velho modelo. No texto, há um jogo entre a sigla MST, que guarda a memória do Movimento dos Trabalhadores Sem Terra, deslocada para o campo das telecomunicações, o que resulta em MST - Movimento dos Sem-Telefone. Desta forma, identifica-se a falta de telefones no Brasil, comparando-a implicitamente ao movimento pela terra. No entanto, o Movimento dos SemTelefone é inexistente no plano social, em termos institucionais, e de expressão ("o único mudo") e ganha a existência no discurso do autor, como metáfora para relacionar a falta de telefones ao monopólio estatal:

São os 17 milhões de brasileiros, pessoas e empresas, que estão na fila de uma humilde linha telefônica sem obter um mísero chiado do monopólio estatal do malote e do recado. Também integram o MST da Telecomunicação os 7 milhões de brasileiros na fila bola-de-neve do celular, nova paixão nacional.

Compara-se o funcionamento da Telebrás ao de uma estatal soviética, significado negativamente neste discurso. Pela conjunção "ou seja" integra-se a comparação à explicação, bloqueando outras interpretações para "estatal soviética". Dessa forma, o regime comunista funciona como parâmetro de comparação para o que ocorria no Brasil. Observemos que no texto esta aproximação de um ambiente de decadência econômica é argumento para significar o monopólio estatal como algo do passado e também maléfico. Mostra- 
se que os efeitos da política soviética se fazem presentes à epoca na economia e na vida dos cidadãos, já que este passado permanece na expressão adverbial "ainda hoje":

\begin{abstract}
Ainda hoje, na Grande Rússia, consumidores micados aguardam a entrega do primeiro carro particular, devidamente pago há mais de dez anos. E o carro da fila é um lada. Foi essa anorexia econômica que destruiu a União Soviética e respectivos satélites. Sem que fosse preciso disparar um tiro, uma revolta, uma passeata, uma greve, um manifesto.
\end{abstract}

A divisão entre capitalismo e comunismo funciona, portanto, como eixo organizador do discurso. A comparação com a União Soviética produz o efeito de situar o monopólio estatal no passado, como algo ultrapassado. Esta divisão entre capitalismo e comunismo é deslocada para outro espaço geográfico, onde ainda há comunismo: a China. A preposição "até” vem incluir a China entre os que visam superar o monopólio estatal. Notemos ainda que a oração adjetiva explicativa juntamente com o advérbio "ainda” e o verbo "estar" ("que ainda está comunista") definem no comentário do enunciador uma transitoriedade para comunismo, que não está no plano da identidade (ser) nem da permanência. E por flexibilizar o monopólio estatal, este país comunista pode servir como exemplo.

Notemos que há uma continuidade proposta entre a "descoberta de socialistas fabianos na virada do século 20" e “o welfare state" do capitalismo no Atlântico Norte. Dois efeitos podem ser depreendidos: o primeiro é que o capitalismo é uma evolução do socialismo fabiano e o segundo é de que há uma capitalismo "digno do nome" numa região do globo - o Atlântico Norte - o que exclui outras regiões.

Também observamos que "verdadeiramente estratégico" vem significar o que é estratégico para um país, negando a significação proposta pela oposição à privatização. Busca-se, portanto, definir o que é estratégico e o que é soberania nacional, negando-se a interpretação aí contida. Assim, temos:

\begin{abstract}
Investimento estratégico do Estado moderno não é telefone, não é petróleo, não é asfalto, não é energia, não é ferrovia. Soberania nacional é concentrar capitais públicos (escassos) e capitais privados (suplementares) em saúde pública, educação pública, segurança pública, justiça capilar, transporte coletivo, habitação popular, pesquisa básica e programas sociais de emergência.
\end{abstract}

E esta definição resulta no que se considera um papel do governo em um Estado, considerado dentro do discurso empresarial de eficiência: "São funções de governo para todo o sempre. Governo eficiente e enxuto, no conceito do Estado Ótimo e não mais do Estado Máximo ou do Estado Mínimo”. Desta forma, mostra-se que há uma oposição entre dois modelos, definidos como primeiro e segundo, sendo o primeiro vitorioso. 
Há uma "nova percepção universal”. O adjetivo "universal" não abre possibilidade de outra interpretação ou mesmo existência de outras versões, porque há uma história do “segundo modelo" que é rememorada e significada como malsucedida. Localizado como experiência passada, este modelo é, portanto, inviável: “O segundo modelo já foi testado, reprovado e sepultado em esquife de quinta classe no cemitério das utopias fraldadas". Por essa razão, por estar morto, tem-se um novo modelo, vitorioso, em que Estado e mercado não se opõem:

O primeiro modelo, o vitorioso, exige a salvaguarda do Estado arbitral, dono da autoridade (e não da propriedade) do processo econômico. O mercado que se aproxima não está em oposição ao Estado. Essa visão maniqueísta é canastrice ideológica. Mercado que se desenha no horizonte do terceiro milênio não será aberto nem fechado. Será, digamos assim, um mercado liberal dentro da moldura do Estado arbitral. Um mercado regulado ou pactuado, dentro de uma "banda larga" de competição ou concorrência.

(5) O debate em torno da privatização da Telebrás se intensificou muito nas últimas semanas, à medida que se aproxima o leilão. Em particular, o preço mínimo recém-fixado pelo governo vem recebendo críticas da oposição. Este artigo tem como objetivo mostrar que essas críticas carecem de fundamento técnico, sendo explicadas exclusivamente pelo caráter político-eleitoral que esse debate adquiriu.

Antes de mais nada, é preciso entender que a privatização tem um objetivo muito mais amplo do que a obtenção da receita por parte do governo. No caso específico das telecomunicações, o que se pretende com o leilão é uma total revolução no setor, quebrando o regime de monopólio atual e promovendo a universalização do acesso ao telefone. Vale lembrar que o modelo que se pretende enterrar manteve por décadas a maior parte da população sem telefone, enquanto aqueles que podiam pagavam vários milhares de reais por uma linha. Há, portanto, uma enorme diferença entre a Telebrás em regime de monopólio e a Telebrás em regime de competição e com universalização de serviços.

É claro que essa diferença tem um preço. É muito fácil entender o motivo. O novo modelo prevê que o futuro dono da Telebrás estará submetido à competição, com tarifas telefônicas cada vez menores. Além disso, o comprador se compromete a cumprir metas de universalização no fornecimento de linhas e garante qualidade muito superior à atual no serviço prestado ao consumidor. Por fim, a Telebrás privatizada terá custos adicionais, como despesas de concessão e de comercialização, uma vez que passará a ter de brigar por clientes. O market share da empresa será obviamente menor, pois haverá competição. (A VERDADE..., 1998, p. A3).

Observemos que em (5) o sujeito se coloca na posição de argumentar, de detentor de uma verdade que pode ser demonstrada e explicada, assumindo o tom didático. Dessa forma, visa mostrar que os argumentos do outro, ou seja, da oposição não são válidos - "carecem de fundamento técnico, sendo explicadas exclusivamente pelo caráter político-eleitoral que esse debate adquiriu”. Situase assim a política-eleitoral apenas do lado da oposição, produzindo o efeito de que o governo não é parte desta política nem coaduna com ela. A partir da aceitação de que há uma verdade a ser demonstrada e passível de ser conhecida objetivamente, o sujeito assume a posição do enunciador genérico, que explicará e se oculta na objetividade de sua fala . A expressão “é preciso” 
("é preciso entender que a privatização tem um objetivo muito mais amplo do que a obtenção da receita por parte do governo") e a partícula "se", que indetermina o sujeito ("o que se pretende com o leilão é uma total revolução no setor, quebrando o regime de monopólio estatal e promovendo a universalização do acesso ao telefone") são marcas desta adesão a uma perspectiva universal.

Notemos que a revolução é definida pela quebra do monopólio estatal, que tem como resultado a universalização do acesso ao telefone. Nesta rede causal, portanto, este sujeito promove o deslocamento para o passado justificando a necessidade de quebra deste monopólio, gerador de escassez e privilégios: "Vale lembrar que o modelo que se pretende enterrar manteve por décadas a maior parte da população sem telefone, enquanto aqueles que podiam pagavam vários milhares de reais por uma linha". Este passado insatisfatório que deixará de produzir seus efeitos está, portanto, na dependência da quebra do monopólio. O passado é a Telebrás em regime de monopólio que se opõe a Telebrás em regime de competição e com universalização de serviço. Esta diferença vem justificar o preço estabelecido pelo governo para a venda das empresas.

\section{Considerações finais}

Há em ambos os jornais uma tomada de posição ${ }^{[4]}$ privatista que organiza a memória em prol da privatização, buscando legitimá-la e institucionalizá-la como dominante. A privatização é considerada primeiramente como um marco simbólico, um ponto a partir do qual se reconfigura a história das telecomunicações. No discurso dos jornais, ela aponta para mudanças consideradas necessárias na sociedade brasileira para que esta avance em direção à modernidade ocidental. A privatização assume assim um significado "histórico". Este acontecimento é classificado pela mídia como histórico e ser histórico significa ser importante, positivo e necessário. A ênfase na fundação de um novo tempo apaga a complexa correlação de forças político-econômicas que intervêm no processo e o conjunto de medidas de governo necessários para que ela se concretize.

Neste discurso, a privatização, portanto, assume os sentidos positivos, o caminho para a mudança e transformação de um setor econômico em crise e que não consegue mais atender às necessidades da sociedade. O significado histórico atribuído pelos jornais à privatização contribui para sua legitimação. É na gestão do tempo, atribuindo significados para o passado e para o futuro, que nesta formação discursiva produzem-se efeitos de verdade. Mostramos que este fato histórico, compreendido apenas como algo marcante e que aponta para mudanças, possibilita que este discurso rompa os vínculos com um passado que ele mesmo constrói. Dessa forma, a imagem construída da história das telecomunicações no Brasil é a de efeitos negativos para a sociedade, 
principalmente porque em boa parte deste passado o Estado deteve o monopólio dos serviços de telecomunicações. Ao negar o passado, abre-se espaço para determinar uma ruptura no discurso e para que se estabeleçam os vínculos da privatização com o futuro. Assim, o passado associa-se ao monopólio estatal, ao Estado como investidor e operador do sistema de telecomunicações brasileiro. Negar o passado significa rejeitar, nesta formação discursiva, benefícios ou possibilidades de continuidade desta história.

\section{Referências bibliográficas}

A VERDADE sobre o preço da Telebrás. O Estado de S. Paulo, 21/6/98, p.A3 BETING, J. Telebrás soviética. O Estado de $S$. Paulo, 29/7/98, p. B2 CERTEAU, Michel de. A escrita da história. Rio de Janeiro: Editora Forense Universitária, 1982, 345p.

ELIAS, Norbert. Sobre o tempo. Rio de Janeiro: Zahar Editores, 1998, 165p GORON, Felipe. e LEWIN, Sérgio.. A Telebrás e os novos tempos. Folha de $S$. Paulo, 4/8/98, p.2-2

HENRY, Paul. A história não existe? In: ORLANDI, E. P. (org.). Gestos de leitura. Campinas: Pontes/UNICAMP, 1994, p. 29-53

LE GOFF, Jacques. História e memória. 2. ed. Campinas: Editora da Unicamp, 1992, 553p.

MARIANI, Bethania Sampaio Corrêa. Os primórdios da imprensa no Brasil (ou: de como o discurso jornalístico constrói memória). In: ORLANDI, E (org.). Discurso fundador, Campinas: Ed. Pontes, 1993, p. 31-42

. Sobre um percurso de análise do discurso jornalístico - a

revolução de 30. In: INDURSKY, Freda; FERREIRA, Maria Cristina Leandro (orgs.). Os múltiplos territórios da Análise do Discurso. Porto Alegre: Sagra Luzzato, 1999, p. 102-121

NASSIF, Luís . Privatização e agências de regulação. Folha de S. Paulo, 2/5/97, p. 2-2

NÓBREGA, Mailson da. Telefone virou presente de Natal. Quem diria? Folha de S. Paulo, 25/12/98, p.2-2

ORLANDI, Eni. Pulcinelli. A interpretação: autoria, leitura e efeitos do trabalho simbólico. 2. ed. Petrópolis, Vozes, 1998, 150p

PÊCHEUX, Michel. Semântica e discurso: uma crítica à afirmação do óbvio.

Campinas: Editora da Unicamp, 1997, 317p . Papel da memória. In: Achard, P. et al. Papel da memória. Campinas : Pontes, 1999, p. 49-57.

Pontes, 2002, 68p . O discurso: estrutura ou acontecimento. Campinas: Editora

\footnotetext{
${ }^{[1]}$ Todos os grifos são nossos.
}

[2] Para Pêcheux (1997, p. 162), o conceito de interdiscurso corresponde ao"todo complexo com dominante" de formações discursivas, que determinam o que pode e deve ser dito, sob a dominação de formações ideológicas.

[3] Pêcheux (1997: 127) explica que o sujeito universal situa-se "em toda parte e em lugar nenhum", sendo aquele que pensa por meio de conceitos. Neste caso, há apagamento da situação.

[4] Para Pêcheux (2002:57), as tomadas de posição são “efeitos de identificação assumidos e não negados" 
